\title{
Analisis faktor-faktor penghambat dalam pengadaan barang milik daerah di Kota Bitung
}

\author{
STEADY BENT' TAMPANATU ${ }^{1}$, HERMAN KARAMOY ${ }^{2}$, JESSY D. L WARONGAN ${ }^{3}$ \\ ${ }^{123}$ Program Magister Akuntansi, Fakultas Ekonomi dan Bisnis Universitas Sam Ratulangi \\ email:steadytampanatu@gmail.com ${ }^{1}$,hkaramoy@yahoo.com ${ }^{2}$,jdimarcus@gmail.com ${ }^{3}$
}

\begin{abstract}
The development and tecnological progress in procurement of goods in the city of Bitung make procurement official need to choose and observe about the providers of goods and services quaity and can provide benefits as big as to the existing society based on presidential rules on the procurementof goods and services. The study is a qualitative exploratory research. Respondents were chosen by purposive sampling. Data were collected by interviews, observation and documentation. Triangulation was conducted to validate data. This study concludes: (1) Procurement officers have not been able to perform their role in determining quality goods and services providers because they are still viewed as routines jobs; (2) Educational background and length of tenure as procurement officers do not affect the quality of goods and services produced by city government of Bitung; (3) Training and technical guidance are intended to improve the quality of human resources, however the results of such activities are not optimal yet; (4) Communication is a supporting factor in the procurement process between the commitment maker and the procurement officer; (5) Personal or group interests, which always take precedence in the implementation of procurement of goods and services, have closed the opportunity to the other providers to supply their goods and or services.
\end{abstract}

Keywords: Resources, Bureaucratic Structure, Communication and Disposition

Abstrak. Adanya perkembangan dan kemajuan teknologi dalam pengadaan barang dipemerintahan Kota Bitung menjadikan pejabat pengadaan perlu memilih dan mencermati tentang penyedia barang dan jasa yang berkualitas dan dapat memberikan manfaat yang sebesarnya kepada masyarakat yang ada berdasarkan aturan presiden tentang pengadaan barang dan jasa.Penelitian dilakukan dengan menggunakan metode penelitian kualitatif dengan pendekatan eksploratif (exploratory approach). Pemilihan responden mengunakan purposive sampling. Teknik pengumpulan data digunakan teknik wawancara, observasi dan dokumentasi. Dalam validitas data digunakan metode triangulasi. Berdasarkan hasil analisis dan pembahasan maka dapat disimpulkan bahwa: (1) Para pejabat pengadaan barang dan jasa yang menjadi informan cenderung belum dapat melakukan perannya dalam menentukan penyedia barang dan jasa yang berkualitas, karena masih dipandang pekerjaan tersebut sebagai suatu pekerjaan rutinitas; (2) Latar belakang pendidikan dan lamanya masa jabatan sebagai pejabat pengadan tidak mempengaruhi kualitas barang dan jasa yang dihasilkan oleh pemerintah Kota Bitung; (3) Dalam meningkatkan kualitas sumber daya manusia pelatihan atau bimbingan teknis menjadi salah satu sarana yang sering diikuti pejabat pengadaan tetapi hasilnya belum maksimal terkesan hanya untuk realisasi penyerapan anggaran; (4) Komunikasi menjadi faktor pendukung ditahapan proses pengadan antara pejabat pembuat komitmen dan pejabat pengadaan; (5) Kepentingan pribadi atau kelompok, yang selalu didahulukan dalam pelaksanaan pengadaan barang dan jasa tanpa membuka ruang dan kesempatan yang sama kepada pihak penyedia yang lain.

Kata Kunci: Sumber daya, Struktur Birokrasi, Komunikasi dan Disposisi 


\section{Pendahuluan}

Pengadaan barang dan jasa pemerintah merupakan seluruh proses belanja barang dan atau jasa yang dilakukan oleh kementerian/lembaga/pemerintah daerah atau institusi pembiayaannya melalui APBN/APBD, baik sebagian atau keseluruhan. Proses tersebut harus mengacu kepada peraturan yang berlaku yaitu keputusan Presiden nomor 4 tahun 2015 tentang pengadaan barang dan jasa pemerintah. Hal ini dilakukan agar proses pengadaan barang dan jasa tersebut dapat dilaksanakan efektif dan efisien dengan prinsip persaingan sehat, transparan, terbuka dan perlakuan yang adil bagi semua pihak, sehingga hasilnya dapat dipertanggungjawabkan baik dari segi fisik keuangan maupun manfaatnya bagi kelancaran tugas pemerintah dalam pelayanannya kepada masyarakat.

Pada dasarnya pengadaan barang dan jasa yang ada dilingkungan pemerintah mengalami berbagai dinamika aturan dan kebijakan, baik kualitasnya maupun kuantitasnya. Dalam pengadaan barang dan jasa, aturan dan mekanisme pengadaan sudah sangat jelas lewat regulasi yang sudah ditetapkan oleh pemerintah, akan tetapi persoalan pengadaan barang dan jasa belum dapat menjawab akan harapan masyarakat yaitu barang yang berkualitas sehingga menimbulkan berbagai pertanyaan di dalam masyarakat tersebut. Hal ini membuat kita bertanya ada apa yang terjadi dengan proses pengadaan barang dan jasa pemerintah. Begitu banyak permasalahan yang terjadi dalam pengadaan barang dan jasa yang ditemui, baik dari segi proses perencanaannya, administrasinya dan pengadaannya itu terjadi berbagai persoalan. Kemampuan dalam segi pengawasan oleh pihak penyelenggara seringkali tidak dapat di andalkan karena dipengaruhi oleh berbagai faktor misalnya, faktor ketrampilan, pengetahuan dan lain sebagainya yang menjadi tuntutan dalam pelaksanaan pengadaan barang dan jasa milik pemerintah.

Dalam berbagai hal pengadaan barang dan jasa mengalami perkembangan yang sangat maju sehingga menuntut kemampuan yang dapat diandalkan baik secara perseorangan maupun sebagai suatu institusi penyelenggara pengadaan barang dan jasa. Pada setiap seorang pejabat pengadaan barang dan jasa harus dapat melaksanakan aturan dan kriteria pengadaan barang dan jasa yang sudah diamanatkan dalam peraturan pemerintah yaitu peraturan presiden no 4 tahun 2015 tentang pengadaan barang dan jasa, dengan menjamin proses pengadaan barang dan jasa yang berkualitas. Kebutuhan akan barang dan jasa yang berkualitas baik dan tepat serta sesuai kebutuhan, membutuhkan suatu kerja yang efektif dan efisien dimana barang dan jasa tersebut dapat membawah manfaat kepada para penggunanya, bukan sekedar untuk memenuhi target dan pemenuhan kebutuhan anggaran, yang seharusnya dilandasi akan kualitas barang dan jasa yang baik.

Banyak para pegawai negeri sipil khususnya yang menjabat pejabat pengadaan barang dan jasa belum dapat memahami sepenuhnya, yang dimaksudkan dengan pengadan barang dan jasa yang menjadi tanggung jawab kerjanya, yaitu pengadaan barang dan jasa pemerintah, dikarenakan para pejabat pengadaan barang dan jasa hanya sekedar melakukan pengadaan barang dan jasa tampa mempedulikan aspek kualitas dalam pengadaan barang dan jasa pemerintah, ini menjadi suatu gambaran yang sangat tidak baik untuk masa yang akan datang, karena orientasi pekerjaan dari pejabat pengadaan akan menentukan keberadaan penyedia barang dan jasa yang berkualitas baik, juga akan dirasakan baik oleh pemerintah maupun oleh masyarakat pada umumnya.

Kebutuhan akan barang dan jasa dapat dipastikan setiap tahun akan terjadi, disetiap satuan kerja pemerintah, itupun terjadi di pemerintah Kota Bitung, dimana setiap tahun anggaran yang baru selalu diadakan pengadaan barang dan jasa secara langsung tidak melalui suatu mekanisme tender atau dilakukan langsung oleh pejabat pengadaan, yaitu belanja pengadaan barang dan jasa yang menyangkut operasional dan kebutuhan pegawai negeri sipil di setiap satuan perangkat kerja daerah Kota Bitung, akan tetapi banyak kejadian yang terjadi jumlah barang dan jasa yang ditetapkan dalam APBD lewat anggaran di satuan perangkat daerah tidak dapat dilakukan dengan baik, berupa barang dan jasa yang diminta tidak sesuai 
dari segi kualitas. Ini yang sering terjadi dalam pengadaan barang dan jasa, sebab praktek yang dilakukan hanya untuk memenuhi aspek kebutuhan anggaran tersebut.

Dalam kondisi tersebut diatas tentu tidak sesuai dengan peraturan yang sudah ditetapkan oleh pemerintah dalam pengadaan barang dan jasa, sebagai pejabat pengadaan dan yang melakukan pengadaan tentu kondisi tersebut sangat tidak baik dalam pelaksanaan pengadaan barang dan jasa, sehingga dapat merugikan keuangan pemerintah. Pada peraturan pemerintah yaitu perpres nomor 54 tahun 2010 sebagaimana telah diubah terakhir kalinya dengan peraturan Presiden nomor 4 tahun 2015 tentang pengadaan barang/jasa pemerintah yaitu pada: pasal 6 point a, pasala 12 ayat 1 dan pasal 89 ayat 2 a.

Keberadaan pejabat pengadaan pengadaan dalam pengadaan barang dan jasa pemerintah sangat penting sehingga pengambil keputusan untuk pengadaan barang dan jasa selalu bekerjasama dengan pengguna anggaran disatuan perangkat kerja daerah atau kuasa pengguna anggaran, karena tidak menutup kemungkinan anggaran yang disediakan belum dapat mencukupi dari kebutuhan yang ada, sehingga yang terjadi pengadaan barang dan jasa tidak dapat berjalanan sesuai dengan kebutuhan dan peruntukannya maka peneliti tertarik untuk melakukan "Analisis Faktor-Faktor Penghambat Dalam Pengadaan Barang Milik Daerah di Kota Bitung"

\section{Model Analisis}

Model analisis pada penelitian ini telaah pustaka, baik teoritis maupun fenomena yang terjadi saat ini, maka kerangka pemikiran dalam penelitian ini mengenai adalah bagaimana faktor faktor yang mempengaruhi kualitas pengadan barang dan jasa yang didalamnya ada pejabat pengadaan barang dan jasa, yang sangat berperan untuk melaksanakan system dan prosedur pengadaan barang dan jasa pemerintaha daerah Kota Bitung.

Gambar 1. Model Analisis

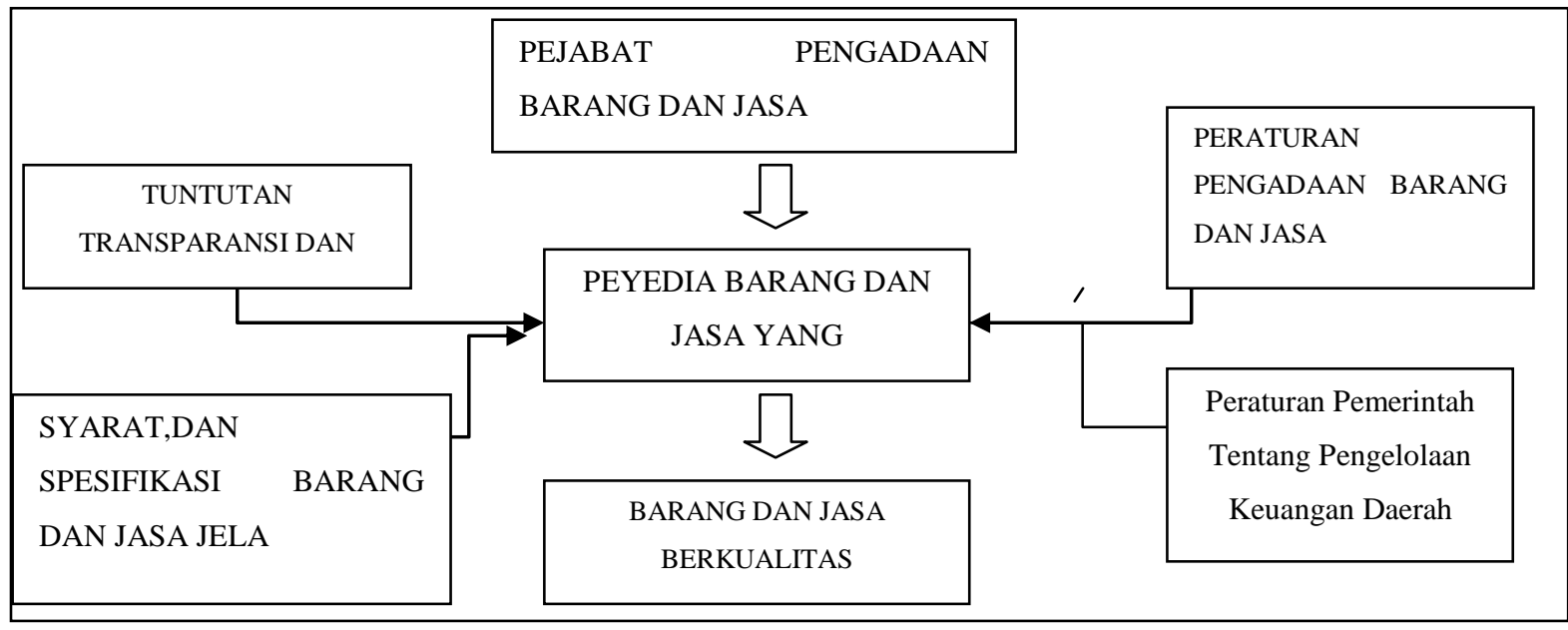

\section{Metode Penelitian}

Metode Penelitian adalah cara-cara berpikir, berbuat untuk dipersiapkan secara baik untuk mencapai tujuan penelitian. Dalam Penelitian ini, metode penelitian yang digunakan oleh peneliti adalah metode eksploratori (exploratory approach) dengan pendekatan induktif, yaitu suatu pendekatan dengan mengambil suatu kesimpulan secara umum dari fakta-fakta nyata dilapangan. Pendekatan kualitatif menurut Sugiyono (2008: 14) adalah merupakan metode análisis yang berlandaskan pada filsafat postpositivisme, digunakan untuk meneliti pada kondisi objek yang alamiah, dimana peneliti adalah sebagai instrumen kunci. Metode eksploratori menurut Arikunto (2010:32), adalah metode penelitian yang bertujuan untuk menggali suatu informasi. Amirin (2009) mendefinisikan Penelitian eksploratif merupakan salah satu pendekatan penelitian yang digunakan untuk meneliti sesuatu (yang menarik perhatian) yang belum diketahui, belum dipahami, belum dikenali, dengan baik. Menurut 
Ibrahim (2015:60) pengertian penelitian eksploratif adalah cara kerja penelitian yang dimaksud untuk menemukan lebih jauh dan mendalam terhadap kemungkinan-kemungkinan lain dari masalah yang diteliti.

Pendekatan eksploratori dalam penelitian kualitatif adalah cara kerja penelitian yang dimaksudkan untuk menemukan lebih jauh dan mendalam terhadap kemungkinankemungkinan lain dari permasalahan yang diteliti. Dengan pendekatan eksploratori, penelitian tidak lagi sekedar menggambarkan atau melukiskan atau menjelaskan seperti apa adanya realitas yang dikaji sebagaimana pada metode deskriptif. Namun tidak melalui tahapan uji coba sebagaimana pada metode eksperimen (Ibrahim, 2015:64). Menurut Creswell (2012:206) tujuan penelitian kualitatif adalah tidak untuk menggeneralisasi ke populasi, tetapi untuk mengembangkan eksplorasi mendalam terhadap inti fenomena.

Pendekatan eksploratori berupaya menemukan informasi secara lebih lengkap dan mendetail mengenai sesuatu topik atau masalah yang belum dipahami sepenuhnya oleh peneliti. Dengan kata lain, penelitian ini bertujuan untuk menganalisis peran pejabat pengadaan dalam kualitas pengadaan barang dan jasa di Pemerintah Kota Bitung dan peraturan daerah yang mendasarinya.

Jenis penelitian yang dilakukan adalah metode data eksplorasi yang dimaksudkan untuk menemukan lebih jauh dan mendalam terhadap kemungkinan-kemungkinan lain dari permasalahan yang diteliti. Dengan metode eksplorasi, peneliti tidak lagi sekedar menggambarkan atau melukiskan atau menjelaskan seperti apa adanya realitas yang dikaji sebagaimana pada metode deskriptif. Namun tidak juga melalui tahapan uji coba sebagaimana pada metode eksperimen.

\section{Analisis dan Pembahasan}

Penelitian dilaksanakan di kantor pemerintah Kota Bitung dengan terlebih dahulu menyampaikan surat izin penelitian kepada pimpinan daerah Kota Bitung melalui sekertaris daerah Kota Bitung, untuk mendapatkan data primer maupun sekunder melalui kegiatan wawancara, studi dokumentasi, dan observasi lansung dilapangan. Penelitian ini dilaksanakan selama \pm 5 (lima) bulan yakni antara bulan Nopember, desember tahun 2017 dan dilanjutkan pada bulan Januari, pebruari sampai bulan maret tahun 2018. Dalam melakukan penelitian, peneliti menggunakan instrumen-instrumen pendukung diataranya: buku catatan (notebook), pedoman wawancara (lampiran 1), alat perekam berupa audio/video recorder (handycam) untuk merekam pelaksanaan wawancara dengan informan yang hasilnya di transkrip menjadi transkrip data (lampiran 3), kamera untuk mendokumentasikan kegiatan penelitian dilapangan (lampiran 4), laptop untuk menunjang penulisan hasil penelitian. Data hasil penelitian berupa wawancara, kemudian dilakukan organisasi data. Peneliti mengetik hasil interview menjadi interview transcription, kemudian melakukan content analysis untuk menganalisis interview transcription. Dapat dijelaskan bahwa setelah melakukan wawancara, analisis data dimulai dengan membuat transkrip hasil wawancara, dengan cara memutar kembali rekaman hasil wawancara, mendengarkan dengan seksama, kemudian menuliskan kata - kata yang didengar sesuai dengan apa yang ada direkaman tersebut kemudian melakukan kategorisasi/coding atau penentuan tema untuk menjawab permasalahan: (1) bagaimana peran pejabat pengadaan dalam proses pelaksanaan pengadaan barang dan jasa; (2) apa saja yang menjadi kendalakendala dalam proses pengadaan barang dan jasa (3) bagaimana upaya yang dilakukan untuk mengatasi kendala pengadaan barang dan jasa serta teori agency, psychological theory, dan teori implementasi kebijakan. Penelitian menemukan kategorisasi/coding atau tema yang diorganisasikan Pejabat pengadaan barang dan jasa di berbagai intansi pemerintah baik pusat maupun daerah adalah pejabat pengadaan yang dipilih dan diangkat oleh setiap satuan perangkat kerja yang ada berdasarkan atas suatau keahlian yang dimiliki orang tersebut dengan bukti adanya sertifikat pengadaan barang dan jasa. Dalam fungsinya sebagai pejabat pengadaan melakukana kewajiban untuk dapat mengadakan pengadaan barang baik secara penunjukan langsung atau bisa di lelangkan. 
Pejabat pengadaan barang dan jasa di berbagai intansi pemerintah baik pusat maupun daerah adalah pejabat pengadaan yang dipilih dan diangkat oleh setiap satuan perangkat kerja yang ada berdasarkan atas suatau keahlian yang dimiliki orang tersebut dengan bukti adanya sertifikat pengadaan barang dan jasa. Dalam fungsinya sebagai pejabat pengadaan melakukana kewajiban untuk dapat mengadakan pengadaan barang baik secara penunjukan langsung atau bisa di lelangkan. Pejabat pengadaan barang dan jasa yang ada di setiap intansi pemerintah seluruh Indonesia mempunyai tugas dan tanggung jawab yang sangat penting, dikarenakan fungsi dimilikinya sangat strategis karena harus memenuhi persyaratan sebagai berikut:

a. Memiliki integritas, disiplin, dan tanggung jawab dalam melaksanakan tugas;

b. Memahami pekerjaan yang akan diadakan;

c. Memahami jenis pekerjaan tertentu yang menjadi tugas ULP/Kelompok Kerja ULP/Pejabat Pengadaan yang bersangkutan;

d. Memahami isi dokumen, metode dan prosedur pengadaan;

e. Memiliki sertifikat keahlian pengadaan barang/jasa sesuai dengan kompetensi yang dipersyaratkan; dan

f. Menandatangani Pakta Integritas.

Dalam kenyataannya pejabat pengadaan juga mempunyai tugas pokok sebagai pejabat pengadaan yang dalam hai ini kewenangan yang dimilikinya untuk pengadaan barang dan jasa karena itu dapat dijabarkan sebagai berikut:

a. Menyusun rencana pemilihan penyedia barang /jasa;

b. Menetapkan dokumen pengadaan;

c. Menetapkan besaran nominal jaminan penawaran;

d. Mengumunkan pelaksanaan pengadaan barang/jasa di website kementerian/lembaga/pemerintah daerah/ instansi masing-masing dan papan penguman resmi untuk masyarakat serta menyampaikan ke LPSE untuk diumumkan dalam portal pengadaan Nasional;

e. Menilai kualifikasi penyedia barang/jasa melalui prakualifikasi atau pascakualifikasi;

f. Melakukan evaluasi administrasi, teknis dan harga terhadap penawaran yang masuk

g. Khusus pejabat pengadaan yaitu menetapkan penyedia barang/jasa untuk pengadaan langsung paket pengadaan barang/pekerjaan kontruksi/jasa lainnya yang bernilai paling tinggi Rp. 200.000.000,00,- (dua ratus juta rupiah) dan/atau

h. Pengadaan langsung atau penunjukan langsung untuk paket pengadaan jasa konsultasi yang berniali paling tinggi Rp 50.000.000,00,- (lima puluh juta rupiah);

i. Menyampaikan hasil pemilihan dan salinan pemilihan penyedia barang/jasa kepada PPK

j. Menyerahkan dokumen asli pemilihan penyedia barang/jasa kepada PA/KPA, dan

k. Membuat laporan mengenai proses pengadaan kepada PA/KPA

1. Memberikan pertanggung jawaban atas pelaksanaan kegiatan pengadaan barang/jasa kepada PA/KPA.

Pertanyaan tentang peran pejabat pengadaan terhadap kualitas pengadaan barang dan jasa pemerintah Kota Bitung, disampaikan oleh informan mendapatkan informasi bagaimana tahapan pelaksanaannya serta kendala atau masalah baik pada implementasi maupun pada hasil laporan yang disampaikan. Selain itu juga apa pengaruh sosialisasi teknis atau bimbingan teknis dalam mendukung pengetahuan dan pemahaman tentang kualitas barang dan jasa yang di sediakan oleh para penyedia barang dan jasa di pemerintahan Kota Bitung. Kegiatan pengadaan barang dan jasa dilakukan oleh pejabat pengadaan yang sudah tercantum dalam SK kepala satuan perangkat kerja daerah (SKPD) yang dalam pengangkatannya ditunjuk langsung oleh kepala Dinas atau Badan dengan hanya didasarkan pada kepemilikan sertifikat pengadaan tanpa memperhatikan kualifikasi dari kompetensi pejabat itu sendiri. Hal ini tentu saja akan mempengaruhi hasil akhir pengadaan, dimana output yang dihasilkan tidak sesuai dengan yang diharapkan. 
Selain itu, jabatan yang disandang oleh pejabat pengadaan tidak hanya berfokus pada bidang pengadaan barang dan jasa pemerintah, melainkan pada tugas pokok dan tanggungjawabnya sebagai pegawai negri sipil di instansi pemerintahan yang didudukinya. Dengan kata lain, tugas pengadaan merupakan tugas tambahan, yang tentu saja porsi pertanggungjawabnya tidak bisa dioptimalkan. Melihat pengadaan yang sumber anggarannya berasal dari APBD/APBN yang tentu saja nilainya tidak sedikit jumlahnya, namun perlakuannya tidak bisa dioptimalkan, maka jelas prinsip pengadaan yang dijadikan sebagai pedoman pengadaan telah diabaikan.

Melihat kondisi yang juga merupakan gambaran pengadaan di Kota Bitung, maka perlu perhatian kusus terkait peningkatan kompetensi pejabat pengadaan. Kompetensi merupakan tolak ukur terpenting yang menjadikan pejabat bersikap professional. Dalam hal ini pengatahuan dan peran pejabat pengadaan, peneliti mencoba untuk mengali informasi dari informan yang peneliti tetapkan kriteria informannya. Tingkat pemahaman ekstrapolasi yang dibutuh oleh pejabat pengadaan barang dan jasa dalam memahami peran pejabat pengadaan terhadap kualitas barang dan jasa yang menjadi tuntut sekarang ini berdasarkan peraturan presiden no 4 tahun 2015 tentang pengadaan barang dan jasa yaitu membutuhkan kemampuan tertentu yang mengutamakan ketrampilan dalam suatu sisitem tata kelola yang telah dikenal luas didunia usaha, untuk menyelesaikan suatu pekerjaan atau segala pekerjaan dan /atau penyediaan barang dan jasa.selain dokumen pengadaan yang memuat informasi dan ketentuan yang sharus ditaati oleh para pihak dalam proses pengadaan barang dan jasa.

Sumber daya manusia adalah potensi yang menjadi motor penggerak organisasi, baik organisasi swasta maupun organisasi publik. Pejabat Pengadaan pun adalah sumber daya manusia yang dalam melaksanakan tugas dan tanggung jawabnya perlu mempunyai kualitas. Kualitas SDM harus selalu ditingkatkan dengan salah satu cara yaitu dengan mengikuti pelatihan atau bimbingan teknis. Sumber daya manusia juga merupakan salah satu variabel yang mempengaruhi keberhasilan dan kegagalan implementasi. Implementasi sangat tergantung pada sumber daya manusia (aparatur). Oleh karena itu sumber-sumber daya manusia harus ada ketepatan dan kelayakan antara keahlian yang dimiliki sesuai dengan tugas pekerjaan sebagai pejabat pengadaan barang dan jasa yang ditanganinya.

Dalam kinerja pejabat pengadaan dituntut untuk dapat konsisten dalam mengolah tanggungjawabnya. Beban tugas, tanggungjawab publik serta tugas tambahan yang dipikulnya menjadikan pejabat pengadaan harus lebih bekerja secara optimal. Untuk itu dibutuhkan sumber daya manusia yang kompetan dalam mengolah pengadaan barang dan jasa pemerintah. Sumber daya manusia yang disyaratkan dalam perpres 54 tahun 2010 pasal $17 \mathrm{f}$ serta perubahan perpres 4 tahun 2015 adalah "setiap pejabat pengadaan haruslah memiliki sertifikat keahlian pengadaan yang sesuai dengan kompetensi yang dipersyaratkan". Namun demikian pernyataan ini menjadi melemah ketika ada pernyataan yang sifatnya bertentangan dengan pernyataan diatas, yakni 'jika dalam sebuah instansi/organisasi pemerintah tidak memiliki pejabat yang memenuhi syarat menjadi pejabat pengadaan, maka boleh diambilkan dari instansi lain". Ketentuan ini merupakan kebijakan yang diambil dari perpres 54 tahun 2010 tentang pengadaan barang dan jasa pemerintah (PBJ) pasal 17(4).

Kedua pernyataan diatas bertolak belakang ketika sebuah pernyataan mengenai pengangkatan pejabat pengadaan diambilkan dari instansi lain", maka bisa diartikan beban tugas yang dipikul pejabat pengadaan bukanlah berasal dari bidang yang ditekuni oleh pejabat pengadaan itu sendiri. Hal ini juga terbukti dari gelar atau jabatan yang disandang oleh pejabat pengadaan. Bermodalkan sertifikat tanpa melihat kualifikasi yang jelas mengenai latar pendidikan atau kemampuan yang dimiliki oleh pejabat pengadaan kepala Dinas atau Badan kemudian mengangkatnya menjadi pejabat pengadaan atau yang disebut dengan penunjukan langsung. Hal ini menjadi berbeda dengan yang diharapkan dalam perpres tentang kompetensi atau sumber daya manusia yang disyaratkan untuk menjadi pejabat pengadaan, untuk menjawab pertanyaan pertanyaan diatas, maka peneliti melakukan dan menggali informasi dari informan yang memiliki latar belakang yang berbeda tentang pemahamannya terhadap 
kualitas sumber daya manusia dan implikasinya dalam menjalankan tugas dan tanggungjawabnya sebagai pejabat pengadaan. Namun sebelum memasuki pertanyaan ini yang kemudian merupakan penilaian terhadap sumberdaya manusia pejabat pengadaan, peneliti terlebih dahulu memberikan pertanyaan pengantar seputar syarat dan tugas pejabat pengadaan. Hal ini menjadi sangat penting ketika tugas dan tanggungjawab sudah pasti dimengerti oleh setiap pejabat pengadaan.

Dalam pelaksanaan pengadaan barang dan jasa peran pejabat pengadaan sangat penting demi kelancaran pengadaan tersebut ketika dalam hal pemilihan penyedia, seorang pejabat pengadaan mampu mengkomunikasikan apa yang menjadi tanggung jawab dan beban kerja dari penyedia dalam pengadaan barang dan jasa. Di pemerintahan Kota Bitung pejabat pengadaan yang ada terlihat tidak dapat memkomunikasikan dengan baik apa yang menjadi tanggung jawab sebagai penyedia terbukti dengan diadakan wawancara kepada beberapa pejabat pengadaan barang dan jasa dengan jawaban yang berbeda-beda dan pemahaman yang begitu banyak serta beragam, selain itu juga komunikasi implementasi kebijakan oleh pejabat pengadaan terdapat tujuan dan sasaran kebijakan yang harus disampaikan kepada kelompok sasaran dalam hal ini penyedia barang dan jasa, hal ini untuk mengurangi kesalahan dalam melaksanakan pengadaan barang dan jasa. Komunikasi dalam pengadaan barang dan jasa memiliki beberapa kebijakan dimensi diantaranya: dimensi transformasi (transmission), kejelasan (clarity) dan konsistensi (consistency).

Salah satu faktor yang mempengaruhi pelaksanaan pengadaan barang dan jasa oleh pejabat pengadaan adalah disposisi atau sikap dari pelaksana kebijakan tersebut. Disposisi adalah watak atau karakteristik yang dimiliki oleh implementor, seperti komitmen, kejujuran dan sifat demokrasi. Dalam pencapaian tujuan dari pengadaan barang dan jasa yang berkualitas menjadi komitmen dari pemerintah Kota Bitung menjadi salah satu kendala seperti pernyataan beberapa informan.

\section{Kendala dalam pengadaan Barang dan Jasa}

Instansi pemerintah, dalam setiap aktivitas pengadaan barang/jasa harus mengacu pada peraturan presiden tentang pengadaan barang dan jasa pemerintah yang berbeda dengan sistem pembelian pada sebuah perusahaan. Perbedaan lainnya adalah bahwa pada aktivitas pengadaan barang dan jasa pemerintah tidak setiap orang boleh melakukan dan terlibat dalam proses pengadaan. Hanya personil yang telah memiliki sertifikat keahlian pengadaan dan ditetapkan sebagai pejabat pengadaan yang berhak melakukan proses pengadaan, sebagimana tercantum dalam perpres 54 tahun 2010.

Perpres nomor 4 tahun 2015 yang merupakan penyempurnaan perpres 54 tahun 2010 menyebutkan bahwa pejabat pengadaan adalah personil yang ditunjuk untuk melaksanakan pengadaan langsung, penunjukan langsung dan E-purchasing. Pekerjaan kompleks dan tambahan poin pekerjaan dibandingkan perpres sebelumnya yang harus dilaksankana dan diemban oleh pejabat pengadaan ini mengindikasikan bahwa tidak mudah untuk menjadi seorang pejabat pengadaan. Diperlukan suatu keahlian untuk dapat menguasai pekerjaan tersebut dan diperlukan sebuah keahlian yang memadai sehingga pelaksanaannya sesuai dengan peraturan perundangan-undangan. Diantara keahlian yang harus dimiliki sorang pejabat pengadaan berkaitan dengan pelaksanaan pengadaan barang dan jasa adalah menguasai proses pengadaan mulai dari persiapan sampai dengan pelaksanaan kontrak pengadaan barang dan jasa.

Seorang pemimpin mempunyai peran yang sangat penting dalam mengatasi kendala yang terjadi oleh pejabat pengadaan lewat pengawasan akan tugas yang akan dilakukannya. Sehinnga tidak dapat dipungkiri kendala yang terjadi dalam pengadaan barang dan jasa itu begitu kompleks, hal ini terjadi dalam ketika pengadaan barang dan jasa akan dilaksanakan oleh pejabat pengadaan. Menurut Mardiasmo (2005:114), orientasi pembangunan sektor publik adalah menciptakan good governance, dimana pengertian dasarnya adalah tata kelola 
pemerintahan yang baik. Sehingga diharapkan pejabat pengadaan dapat mengatasi setiap kendala yang dapat timbul dari adanya pengadaan barang dan jasa.

Berdasarkan teori keagenan memiliki prinsip utama berupa hubungan kerja antara dua pihak yaitu pihak yang memberikan wewenang (principal) dengan pihak yang menerima wewenang (agensi) dalam suatu bentuk kerja sama yang dinamakan dengan "nexus of contract". Agen berperan sebagai pihak yang memberikan kontrak oleh principal untuk bekerja sesuai dengan kepentingan principal. Teori ini dapat diartikan adanya suatu hubungan dua pihak yaitu principal dan agen yang diperintahkan untuk suatu pekerjaan atau jasa dalam suatu kontrak yang mengatasnamakan principal dan memberikan kebebasan penuh untuk agen dalam menentukan kebijakan yang bermanfaat.

\section{Upaya untuk mengatasi kendala pengadaan barang dan jasa}

Selama ini, masih banyak ditemukan aparat birokrasi yang kurang optimal dalam melaksanakan tugas dan fungsi utamanya dalam melayani masyarakat, sehingga masyarakat belum memiliki porsi yang seharusnya dalam ikut mengontrol kinerja pemerintah. Dalam pengadaan barang dan jasa pejabat pengadaan sering mengalami berbagai macam tantangan yang membutuhkan kemampuan baik secara individu mauapun organisasi dalam melaksanakan tugas. Adapun upaya tersebut dilakukan dengan berbagai hal mulai dari peningkatan sumber daya manusia, hubungan birokrasi, komunikasi yang baik dan disposisi yang jelas akan pengadaan barang dan jasa pemerintah. Berangkat dari suatu pemikiran tersebut maka upaya yang dilakukan untuk mengatasi kendala dalam pengadaan barang dan jasa pemerintah, yaitu dengan peraturan presiden nomor 54 tahun 2010 tentang pengadaan barang dan jasa pemerintah. Itupun terjadi perkembangan yang terus menerus dengan perubahan peraturan presiden untuk pengadaan barang dan jasa, dalam menjawab tantangan pengadaan barang dan jasa yang semakin kompleks. Dalam pengadaan barang dan jasa pejabat pengadaan harus mampu mengatasi setiap kendala yang dihadapai karena dinamika pengadaan barang dan jasa semakin banyak. Apalagi tugas yang dibebankan itu sangat besar oleh organisasi pemerintahan yang mengharapkan adanya kemampuan yang baik dalam menyelesaikan tugas, karena dapat memberikan solusi terhadap kendala-kendala dalam pengadaan barang dan jasa yang terjadi. Dalam hal mengatasi sumber daya manusia yang responsibilitas pengadaan barang oleh pejabat pengadaan di setiap satuan kerja perangkat daerah yang ada di pemerintahan Kota Bitung. Dengan memberikan waktu dan kesempatan dalam melakukan perbaikan terhadap kualitas pejabat pengadaan dengan memberikan tambahan dan keluasaan kepada pejabat pengadaan dalam melaksanakan tugasnya. Mengatasi kendala Struktur birokrasi itu dilakukan secara bertahap dan berkesinambungan artinya setiap aparatur Negara dalam hal ini pejabat pengadaan barang dan jasa terus melakukan inovasi dan pembahuruan organisasi yang memungkinkan kemungkinan terjadinya intervensi baik dari kuasa pengguna anggaran dan pejabat pembuat komitmen ketika mengadakan pemilihan langsung pengadaan barang dan jasa dapat terhindarkan.

Memiliki pemahaman tingkat ekstrapolasi berarti seseorang mampu melihat dibalik yang tertulis, dapat membuat estimasi, prediksi berdasarkan pada pengertian dan kondisi yang diterangkan dalam ide-ide atau simbol, serta kemampuan membuat kesimpulan yang dihubungkan dengan implikasi dan konsekuensinya. Tingkat pemahaman ekstrapolasi yang dibutuh oleh pejabat pengadaan barang dan jasa dalam memahami peran pejabat pengadaan terhadap kualitas barang dan jasa yang menjadi tuntut sekarang ini berdasarkan peraturan presiden No 4 tahun 2015 tentang pengadaan barang dan jasa yaitu membutuhkan kemampuan tertentu yang mengutamakan ketrampilan dalam suatu sistem tata kelola yang telah dikenal luas didunia usaha, untuk menyelesaikan suatu pekerjaan atau segala pekerjaan dan /atau penyediaan barang dan jasa.selain dokumen pengadaan yang memuat informasi dan ketentuan yang harus ditaati oleh para pihak dalam proses pengadaan barang dan jasa.

Dalam kinerja pejabat pengadaan dituntut untuk dapat konsisten dalam mengolah tanggungjawabnya. Beban tugas, tanggungjawab publik serta tugas tambahan yang dipikulnya 
menjadikan pejabat pengadaan harus lebih bekerja secara optimal, untuk itu dibutuhkan sumber daya manusia yang kompeten dalam mengolah pengadaan barang dan jasa pemerintah. Sumber daya manusia yang disyaratkan dalam perpres 54 tahun 2010 pasal 17f serta perubahan perpres 4 tahun 2015 adalah "setiap pejabat pengadaan haruslah memiliki sertifikat keahlian pengadaan yang sesuai dengan kompetensi yang dipersyaratkan". Namun demikian pernyataan ini menjadi melemah ketika ada pernyataan yang sifatnya bertentangan dengan pernyataan diatas, yakni "jika dalam sebuah instansi/organisasi pemerintah tidak memiliki pejabat yang memenuhi syarat menjadi pejabat pengadaan, maka boleh diambilkan dari instansi lain". Ketentuan ini merupakan kebijakan yang diambil dari perpres 54 tahun 2010 tentang pengadaan barang dan jasa pemerintah (PBJ) pasal 17(4).

\section{Penutup}

Kesimpulan dalam penelitian ini tentang faktor-faktor penghambat pengadaan barang dan jasa di Kota Bitung dapat disimpulkan sebagai berikut:

1. Para pejabat pengadaan barang dan jasa yang menjadi informan tersebut cenderung belum dapat melakukan perannya dalam menentukan pengadaan barang yang berkualitas, karena masih dipandang pekerjaan tersebut sebagai suatu pekerjaan rutinitas.

2. Latar belakang pendidikan dan lamanya masa jabatan sebagai pejabat pengadaan tidak mempengaruhi kualitas barang dan jasa yang dihasilkan oleh pemerintah Kota Bitung.

3. Dalam meningkatkan kualitas sumber daya manusia khususnya peningkatan peran pejabat pengadaan dan kualitas barang yang dihasilkan lewat pengadaan barang dan jasa tersebut perlu ada pelatihan yang terus menerus dilakukan, atau bimbingan teknis menjadi salah satu sarana yang sering diikuti oleh para pejabat pengadaan. Namun dalam pelaksanaannya program peningkatan kemampuan pejabat pengadaan belum memberikan dampak yang maksimal dan terkesan hanya untuk realisasi penyerapan anggaran program kegiatan tersebut.

4. Komunikasi menjadi faktor pendukung dalam proses pengadaan barang dan jasa antara Pejabat pembuat komitmen dan Pejabat pengadaan barang dan jasa.

5. Kepentingan pribadi atau kelompok, yang selalu didahulukan dalam pengadaan barang dan jasa pemerintah Kota Bitung tanpa membuka ruang dan kesempatan yang sama kepada pihak penyedia barang dan jasa yang lain dalam pengadaan barang dan jasa.

Saran yang diberikan oleh peneliti ini kepada pemerintah Kota Bitung dalam melaksanakan peran pejabat pengadaan barang dan jasa sebagaimana diamanatkan undangundang ke depan antara lain:

1. Perlunya adanya ruang yang sama dan terus menerus dalam peningkatan kapasitas SDM yang tepat bagi para pejabat pengadaan barang dan jasa melalui Bimtek/Diklat/Kursus khususnya dalam pelaksanaan pengadaan barang dan jasa, sehingga para pejabat pengadaan barang dan jasa bisa lebih berkualitas peran mereka dalam pengadaan barang dan jasa sesuai teori sampai pada tahapan pelaksanaan sesuai regulasi bukan hanya berdasarkan pengetahuan yang berasal dari pengalaman pelaksanaan tugas sehingga apa yang telah dibahas dan diputuskan bersama dengan pejabat pembuat komitmen dalam evaluasi pelaksanaannya dapat dipertanggung-jawabkan sesuai peraturan perundangundangan.

2. Struktur Birokrasi perlu diperbaiki karena pejabat pengadaan barang dan jasa perlu berperan secara jelas apa yang dimaksud dengan ruang lingkup tugasnya sebagai pemilih penyedia, sehingga sasaran yang diharapkan yaitu mendapatkan kualitas barang dan jasa yang baik dapat terwujud.

3. Perlunya komunikasi dan kerja sama yang kuat antara pejabat pengadaan barang/jasa dan pejabat pembuat komitmen dalam melaksanakan tugas untuk pengadaan barang dan jasa karena komunikasi yang lancer serta kerja sama yang baik akan dapat tercapai bila masing-masing melaksanakan sesuai perundangan yang ada sehingga pencapaian tujuan pelaksanaan pengadaan barang dan jasa yang berkualitas dapat terlaksana. 
4. Dalam pelaksanaan tugas disposisi yang jelas dan dapat dipertanggung jawabkan akan memudahkan dalam tugas pelaksanaan pengadaan barang dan jasa oleh pejabat pengadaan.

5. Untuk penelitian selanjutnya, perlu adanya penelitian tentang penyebab pejabat pengadaan tidak dapat melaksanakan tugas dengan baik terkait pengaruh kepala dinas atau kepala badan di pemerintahan.

\section{Daftar Pustaka}

Albrecht, C., Kranacher, M. J., \& Albrecht, S. 2008. Asset misappropriation research white paper for the Institute for Fraud Prevention. Institute for Fraud Prevention, Research studies.

Adrian, Sutedi. 2012. "Good Corporate Governance”. Sinar Grafika. Jakarta.

Agustino, Leo. 2016. Dasar-dasar Kebijakan Publik. Bandung: Alfabeta.

Arens, Alvin A., \& Loebecke, James K. 2000. “Auditing an Intergrated Approach”.

Arikunto, Suharsimi. 2010. Prosedur Penelitian: Suatu Pendekatan Praktik. Jakarta: Rineka Cipta.

Amirin, T. M. 2009. Penelitian eksploratori (eksploratif). Diakses melalui tatangmanguny. http://wordpress. com/.

Amirudin, dan Zainal Asikin. 2012. "Pengantar metode Peraturan hukum”, Raja Grafindo Persada, Jakarta.

Aswan, Aswan. 2013. Pengadaan Barang dan Jasa Pemerintah, Rona Pancaran Ilmu: Yogyakarta.

Badan Pemeriksa Keuangan Republik Indonesia 2017. Laporan Hasil Pemeriksaan atas kepatuhan terhadap Ketentuan Peraturan Perundang-undangan Pemerintah Daerah Kota Bitung.

Badzila Daroyani Novitatanigrum, 2014. Akuntabilitas dan Transparansi Pengadaan Barang dan jasa Pemerintah Melalui Electronic Procurement Kota Surabaya. Program Studi Ilmu Adminitrasi Negara, Fisip Universitas Airlangga, Vol. 2, Nomor 1, 2014.

Bastian, Indra. 2006. Akuntansi Sektor Publik: Suatu Pengantar. Penerbit Erlangga.

Bangun, Wilson. 2012. Manajemen Sumber Daya Manusia. Jakarta: Erlangga.

Bungin, Burhan. 2015. Penelitian Kualitatif; Komuniikasi, Ekonomi, Kebijakan, Publik, dan Ilmu Sosial Lainnya. Edisi Kedua Jakarta: Prenada Media Group.

Budisusilo, Suryanto, 2005. "Penilaian dan Pengelolaan Aset Daerah dalam Pembangunan Daerah”. Seminar Nasional, MEP UGM, Yogyakarta, 4 Juni 2005.

Daft, Richard L. 2007. Manajemen. Edisi 6. Diterjemahkan oleh EdwardTanujaya dan Shirly Tiolina. Salemba Empat: Jakarta.

Dwiyanto, Agus.2006. “Transparansi Pelayanan Publik”. Dalam Agus Dwiyanto, ed 2006. "mewujudkan good governance melalui pelayanan publik". Yogyakarta: Gadja Mada University Press.

Eriyanto, 2011. Analisis Isi: Pengantar Metodologi untuk Penelitian Ilmu Komunikasi dan Ilmu-ilmu Sosial Lainnya. Kencana Prenada Media Group: Jakarta.

Eisenhardt, Kathleen. M. 1989. Agency theory: An assessment and review. Academy of management review, 14(1), 57-74.

Bodnar, George H. \& Hopwood, William, S. 2003. Sistem Informasi Akuntansi, Terjemahan Jusuf A. A, Edisi Keenam, Penerbit Salemba Empat Jakarta.

Peraturan Menteri Dalam Negeri Nomor. 31 Tahun 2016 tentang Pedoman Penyusunan APBD Tahun Anggaran 2017. 
Peraturan Presiden Nomor 54 tahun 2010 Tentang Pengadaan Barang/Jasa. Jakarta, Pemerintah Republik Indonesia.

Peraturan Presiden Nomor 70 Tahun 2012. (Perubahan Ke 2 atas Peraturan Presiden) Tentang Pengadaan Barang/Jasa. Jakarta, Pemerintah Republik Indonesia.

Peraturan Presiden Nomor 4 tahun 2015 (Perubahan Ke 4 atas peraturan presiden) Tentang Pengadaan Barang/Jasa, Jakarta, Pemerintah Republik Indonesia.

Peraturan Pemerintah Nomor 71 Tahun 2010 tentang Standar Akuntansi Pemerintah.

Peraturan Pemerintah Nomor 27 Tahun 2014 Tentang Pengelolaan Barang dan Milik Negara/Daerah.

Peraturan Menteri dalam Negeri nomor 2 Tahun 2013. Tentang Pedoman Pengembangan Sistem Pendidikan dan Pelatihan Berbaisi Kompetensi di lingkungan Kementerian dalam negeri dan pemerintah daerah. Jakarta.

Peraturan Menteri Dalam Negeri nomor 19 tahun 2016 Tentang Pedoman Teknis Pengelolaan Barang Milik Daerah.

Peraturan LKPP nomor 5 tahun 2012. Tentang Unit Layanan Pengadaan barang/jasa, Jakarta.

Peraturan LKKP nomor 16 Tahun 2015 Tentang Petunjuk Teknis Pengangkatan dalam jabat fungsional pengelola pengadaan barang/jasa melalui mekanisme pengangkatan dari jabatan lain, Jakarta

Halim, Abdul. 2012. Akuntansi Sektor Publik. Jakarta: Salemba Empat.

Hutapea, Parulian \& Thoha, Nurianna. 2008. Kompetensi Plus. PT Gramedia Pustaka Utama. Jakarta.

Kotler, P. \& Koller, K.L. 2012. "Manajemen Pemasaran. Edisi 12. Jakarta: Erlangga.

Krina, L.L 2003. Indikator dan alat ukur prinsip akuntabilitas, transparansi, dan partisipasi. Jakarta: Badan Perencanaan Pembangunan Nasional.

Maharany Arsyad, La Ode Suriadi, \& Syamsul Anam, 2016. Analisis Pengadaan Barang dan Jasa secara elektronik (E-Procurement) pada LPSE Kota Jurnal Ekonomi Kendari.Jurusan Ilmu Ekonomi. Universitas Halu Oleo, Kendari.Vol.1, No 1:01-11.

Martoyo, Susilo. 2000, Manajemen Sumber Daya Manusia, BPFE, Yogyakarta.

Mardiasmo. 2004, “Otonomi dan Manajemen Keuangan Daerah”. BPFE, Yogyakarta.

Moleong. 2016. Metodologi Penelitian Kualitatif. Edisi Revisi PT. Remaja Rosdakarya: Bandung.

Mulyadi. 2008. Sistem Akuntansi. Jakarta: Salemba Empat.

Muhimatul Kibtiyah, 2016. Pengaruh Kompetensi, Budaya organisasi dan Gaya Kepemimpinan pada efektivitas sisitem pengendalian inter pengadaan Barang/jasa pemerintah. Pasca sarjana Universitas Udayana, 2016.

Notoatmojo, S. 2003. Pengembangan Sumber Daya Manusia. Penerbit.Rineka Cipta: Jakarta.

Nida Qoibi, Mohamad Djasuli. 2012. Pentingnya Kompetensi Pejabat Pengadaan Barang/Jasa Pemerintah (Kota Kabupaten Bangkalan dalam melaksanakan prosedur pengadaan Barang/Jasa berdasarkan Perpres 54 tahun 2010). Universitas Trunojoyo Madura.

Prawirosentono, Suyadi. 1999. Kebijakan Kinerja Karyawan. Yogyakarta: BPFE.

Rivanto, J. 1989. Kualitas dan produktivitas. Jakarta: Lembaga Saran Informasi Usaha dan Produktivitas

Rinie Arifianti, Budi Santoso, \& Lilik Handajani, 2015. Perpektif Triangle Fraud Theory Dalam Pengadaan Barang/Jasa di Pemerintahan Nusatenggara Barat. Fakultas Ekonomi dan Bisnis Universitas Mataram Vol. 11 No 2; 195-213. 
Rizal Wahyu Kusuma. 2015, Pengaruh Kualitas Produk, Harga, Fasilitas dan Emosional Terhadap Kepuasan Pelanggan, Sekolah Tinggi Ilmu Ekonomi Indonesia, Jurnal Ilmu dan Riset Manajemen.Vol.4 No 12.

Sabarno, H. 2007. "Memandu otonomi daerah menjaga kesatuan bangsa", Jakarta Sinar Grafika

Satori, Djam'an \& Aan Komariah. 2013. Metodologi Penelitian Kualitatif, Bandung: Alfabeta.

Siagian, Sondang P. 2003. Teori \& Praktek Kepemimpinan. Rineka Cipta. Jakarta.

Siagian, Sondang P. 2004. Manajemen Sumber Daya Manusia. Bumi Aksara. Jakarta.

Silalahi, Ulbert. 2003. Studi Tentang Ilmu Administrasi. Bandung: Sinar Baru Aglesindo.

Silalahi, Marto.2015. Kebijakan Publik, Cetakan ke-1. Bandung: Yuma Pustaka

Simamora, H. 2001. Manajemen Sumber Daya Manusia edisi pertama, STIE YPKN, Yogyakarta.

Siregar, Doli.D. 2004. Manajemen Aset. Jakarta: Satyatama Graha Tara

Singleton, Hall. 2007. Information Technology Auditing and Assurance, Edisi Kedua, Salemba Empat, Jakarta.

Sopiah. 2008. Perilaku Organisasi. Andi. Yogyakarta.

Sugiono. 2009. Metode Penelitian Kuantitatif dan Kualitatif. Bandung: Alfabeta.

Sunyoto, Danang. 2015. Penelitian Sumber Daya Manusia, Edisi Pertama, Center of Academic Publishing Service (CAPS), Yogyakarta.

Suryanto.2015. Pengantar Ilmu Komunikasi Bandung: CV Pustaka Setia.

Widodo, Joko. 2007. Analisis Kebijakan Publik. Bayu Media Publishing. Malang.

Winarno, Budi. 2002. Kebijakan Publik: Teori dan proses. Media Presindo. Yogyakarta.

Widiyantoro, A.E. 2009. Implementasi Performance Budgeting: sebagai kajian Fenomenologis (Studi kasus Pada Universitas Diponegoro). 